\title{
Sisyphus in the Sand Pit
}

\author{
By Gregory Stephens
}

Spring 2009 Issue of KINEMA

\section{SISYPHUS IN THE SAND PIT: ON THE ICONIC CHARACTER OF SAND, AND HOW THE "ANTI-NATURAL MAN" CATCHES WATER IN WOMAN IN THE DUNES}

While filming Woman in the Dunes (WITD), director Hiroshi Teshigahara repeated that this adaptation of the acclaimed Kobo Abe novel had three main characters: not just a man and a woman but also the sand. Decades later he would remark: "The sand has its own identity."(1)

My study examines how this sand with an autonomous character attracts water, and thereby redeems the anti-natural man. I have three principal, interconnected objectives as a focus:

1) Locate Woman in the Dunes as a key text in the emergent genre of environmental film, i.e. audio-visual narratives that represent or revision the human-nature relationship;

2) Read the film as an allegory about human freedom and community that is both Japanese and archetypal in its revising of the myth of Sisyphus, and in its treatment of gender;

3) Contribute to a theory of visual narrative by exploring how Teshigahara constructs both the literal narrative (entrapment), and the metanarratives of human-nature relationships and existential dilemmas, primarily through visual means.

My analysis of WITD is part of a larger study of environmental films as a genre. Recent studies such as David Ingram's Green Screen and Pat Brereton's Hollywood Utopia have been useful, ${ }^{(2)}$ but global cinema in central to my analysis. Commercial feature films, Hollywood or otherwise, play an important part in my study, but I include more analysis of avant-garde film, documentaries, and animation. And while scholars such as Ingram and Brereton concentrate primarily on plot and ideology, I want to explore other features which constitute these films as a genre, rather than as a category of analysis, with particular attention to visual narrative.

In The Film Experience Timothy Corrigan and Patricia White characterize genres in three ways: each has recurring character types; it follows plot / narrative templates; it has characteristic settings or visual styles. ${ }^{(3)}$ Of the character, narratives, and visual motifs that recur in environmental films (EF), I emphasize those which are most applicable to Woman in the Dunes:

- Some of the most common characters in environmental films are investigators, "city slickers" in nature, and the earth herself (often as animal or element) as a character;

- Environmental films often share with westerns a "quest into the natural world." "(4) Variants may include an "errand in the wilderness," or exile and captivity narratives;

- EF contrasts nature and civilization, the former portrayed as "natural" and even "the true temple,"(5) while civilization is visualized as un-natural, and a locus of destruction.

In EF the "anti-natural man"(6) often goes on a regenerative sojourn into nature. Starting with John Storey's definition of culture as "how we live nature,"(7) it can now be said of human beings that "his nature is to have no nature," as Luc Ferry puts it. ${ }^{(8)}$ The urban man who is confined in a sand pit in WITD is one of those de-naturalized humans whose "second nature" is at odds with first nature. But his close encounter with nature - above all through his Sisyphean struggle with the sand - will reshape him and lead him to revision his concept and practice of "living nature."

This sand has an iconic character and a God-like power; it is capable of both destroying but also, in a sense, of transfiguring those who dwell in its presence. To speak of sand's iconic character is to recognize a doubleness in Teshigahara's view of the function of sand. In the film the sand is indeed a character which acts upon human subjects, as they in turn try to act on the sand. But the notion that the sand "has its own identity" infers that it has a personality or agency independent of humans. By centring a non-human character, WITD is an early instance of the tendency in EF to decentre humans. That is to say, WITD is 
a precursor of environmental film because it gives nature - in the form of sand - a starring role, and gives a form of agency to this sand that is clearly far more powerful that the agency of the humans who live in its domain.

I define iconography as a process of mass-producing and consuming icons, in which people or things are blown up to larger than life size and take on a life of their own. ${ }^{(9)}$ This perspective is useful for Japanese cinema, which has tended to "emphasize the contemplative aspect of images."(10) And it is particularly applicable to the cinematic vision of Teshigahara, who early on professed a preference for "using images more than dialogue."(11) Roger Ebert remarked on how WITD "uses visuals to create a tangible texture - of sand, of skin, of water seeping into sand and changing its nature."(12) Teshigahara centres his visual narrative in the interface between sand and skin. And in the process of observing how sand seeps into skin, and into the consciousness of his characters, Teshigahara and Abe, who wrote the screenplay based on his novel, visualize how the anti-natural "second nature" of modernized, urban humans is brought into closer alignment with the first nature embodied here by the sand dunes.
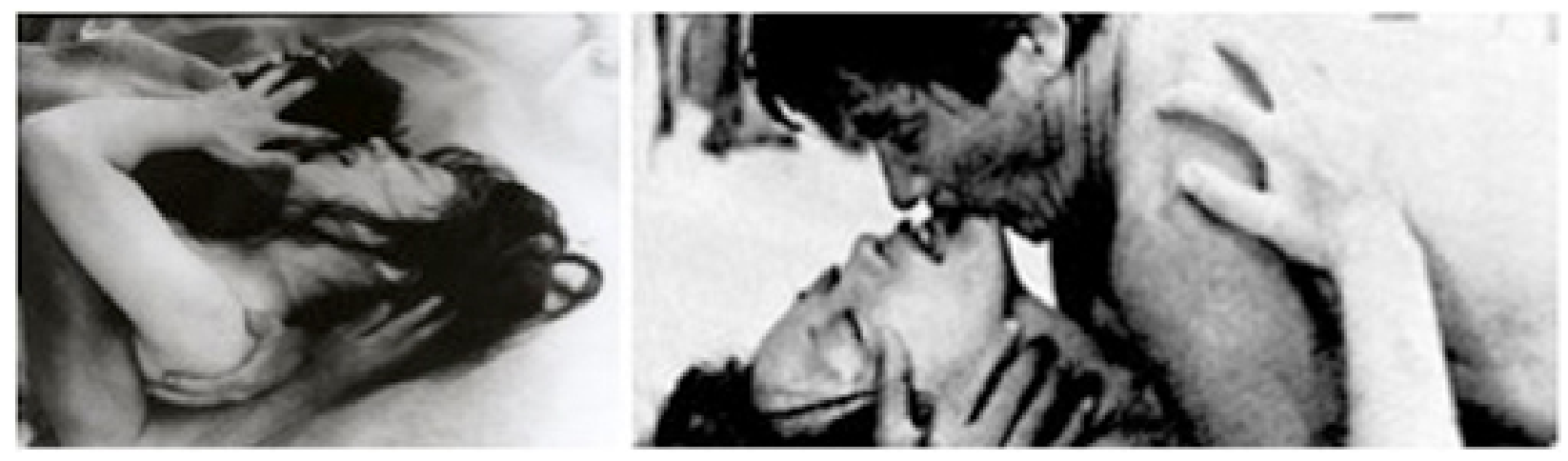

Figure 1:

Teshigahara grew up in an avant-garde art community, and practised pottery. His father Toshu founded Sogetsu, a world-famous flower arranging school. This sensibility shaped his film-making, in collaboration with cinematographer Horishi Segawa. But as James Quandt notes, "Teshigahara's best work...was a masterful amalgam of high international modernism...and traditional Japanese arts."(13) Teshigahara's collaborators were deeply influenced by European film, literature, and philosophy. Abe was an existentialist; Woman in the Dunes was inspired by Camus' The Myth of Sisyphus. Toru Takemitsu, who scored Teshigahara's best films, was a jazz aficionado. And Teshigahara was deeply influenced by French and Italian Neorealist films. ${ }^{(14)}$

WITD is located at a transitional moment between postwar (1946-1965), and contemporary cinema. ${ }^{(15)}$ Influenced by post-WWII existentialism, the film on one level is a critique of the rapid Westernization that Japan underwent after the United States dropped atomic bombs on Hiroshima and Nagasaki. However, there are numerous other ways in which the film anticipates preoccupations and visual themes of contemporary cinema, such as the concern with "dropping out," and an increasing emphasis on the human-nature relationship. (16)

Junpei Niki, the existentialist entomologist, is on the face of it an unlikely candidate to drop out of society, much less to find a resolution to his entrapment and Sisyphean labour through embracing a philosophy of Taoist non-resistance, as Dennis Giles has argued. Niki is a rigid scientific "anti-natural man" who treats living things as objects. At first he feels superior to the woman and the villagers who entrap him. But eventually he finds identity and community through confinement in a village that is subjugated by nature. His argumentative nature is sanded, and eventually restructured, through his relationship to the woman, and to the sand. He attains a form of "salvation" through his "return to nature," as Patricia Erens sees it. (17)

Niki's transformation centres around his willingness to sacrifice for a woman. More broadly, it requires an embrace of communal values, which is visualized by his donning traditional Japanese clothing. Niki finally resolves his existentialist dilemma not but rebelling, as Camus thought was the proper response to a Sisyphean situation (although rebellion is clearly a part of Niki's evolution), but by embracing a more fluid 
Taoist perspective. Although James Quandt emphatically dismisses a Taoist interpretation of this film, I believe that visually it often makes sense. Since the "dwelling place of the Tao" is the "low-ground" (the sand pit here), one must take "the path of least resistance" to achieve this state of balance. One must "be in harmony with, not in rebellion against, the fundamental laws of nature," as Giles writes. ${ }^{(18)}$

"One must imagine Sisyphus happy," felt Camus. Niki eventually finds a form of joy, but in a Japanese, collective way. When Camus wrote, in The Myth of Sisyphus, that "struggle itself... is enough to fill a man's heart," he spoke of the individual. ${ }^{(19)}$ But the resolution Niki eventually finds calls into question the notion of struggle as the desired end. Moreover, the "happiness" is not located merely in one man's heart. But the story has archetypal resonances. WITD is an allegory about the entrapment of "anti-natural man" in a modernism which is shut off from engagement with nature. Recognizing the limits of that world view will require a de-familiarizing of received thought about nature (as sand), and then a revisioning of the scientific method.

\section{The "Unscientific" Nature Of Sand}

With the screen still black, an urban clamour erupts. We see Japanese line art: cartography, or the lines of a dune. Cast are identified by Japanese characters, roman script, fingerprints and seals. Just before the aural city-scape fades, we see an eye squeezed by the ripples pointing in at it. I believe this strategically placed eye has great symbolic power: although the beginning of the film would lead us to see it as trapped, I will later apply the theory of syntagmatic connotation to suggest how the eye takes on a whole new meaning, in retrospect.

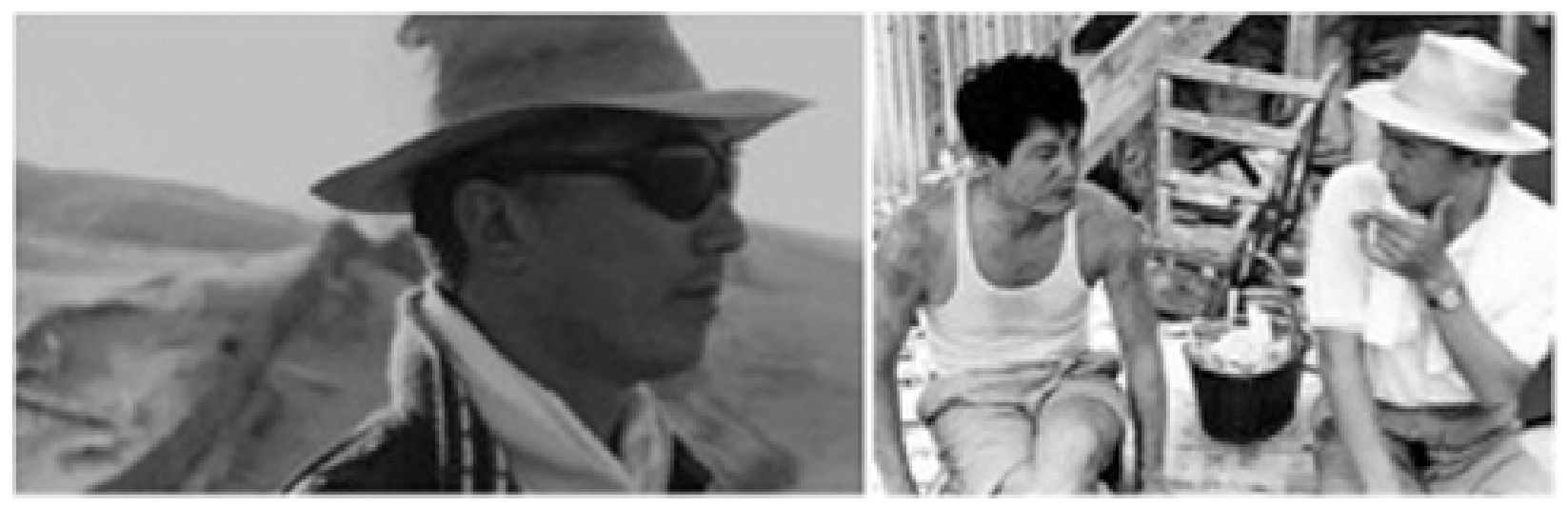

Figure 2: Teshigahara with actor Eiji Okada

The aural city melts into the sounds of classical Bunraku puppet theatre - traditional drums and wooden clappers. The composer hints "that we are about to move from the cacophony of urban life to something older, deeper, and more melodramatic," as Audie Bock observes. ${ }^{(20)}$

The first filmed image is of an apparent crystal which fills the screen - Sisyphus' boulder? The light shifts: it could be a blown-up monstrous insect's head. Then the camera cuts back to reveal what could be a collection of jewels, or a rock pile. A further step back makes it appear that we are looking at about a square inch of something with a form like rock salt.

The next shot, back to about a square metre, leaves no doubt - this is a dune, over which sand blows. The camera pans back, revealing ripples, like furrows in a plowed field. Onto this desolate landscape, trodding straight up the crest of a dune, comes our entomologist.

This montage de-familiarizes sand - prepares us to see it with new eyes. It foreshadows two elements that dominate the film, Anton Bitel writes: "the microscopic scrutiny to which [everything] will be subjected, exposing all manner of hidden complexities," and secondly, "the inescapable ubiquity of sand, covering the sets, caking bared flesh, and filling the soundtrack with its constant presence." (21) That may refer to more than the sound of sand blowing or being dusted off of skin: The first "1/8-millimetre grain influences Takemitsu's intense soundtrack," Andy Beta claims. Given the "circularity" between Takemitsu, who was 


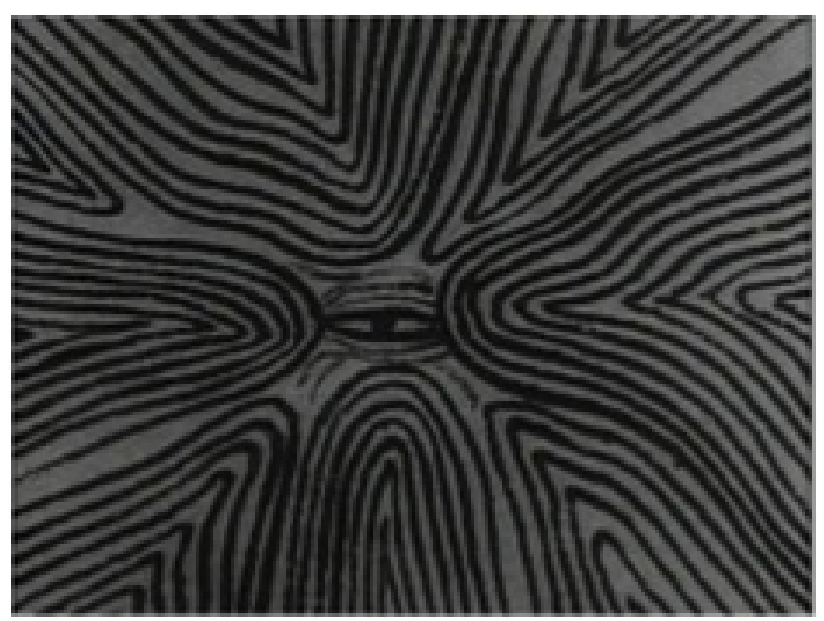

Figure 3:

indebted to Western composers such as John Cage, and Cage's own deep immersion in Japanese music and thought, Takemitsu's score can reasonably be said to have an organic relationship to Teshigahara's film. ${ }^{(22)}$

These two brief segments signal that, in the transition from urban life to "something older, deeper," we will be watching the transfiguration of a solitary city-dweller when he is forced to confront nature, and communal living. We can gather that as a solitary grain of sand seems lifeless, and is a mere object of microscopic contemplation, so too individual humans have little power apart from the collective. But when we place the solitary grain or individual in relation to a larger context, both take on new meanings. The community of sand is not lifeless: it takes on a life of its own. In its collective power, it escapes the stereotypes we have about the properties of sand: that it is dry and devoid of organic matter. In fact, a central theme of the film is that sand, as a collective element, attracts water and produces new life.

Once the urban investigator descends into the pit from which there is no exit, ${ }^{(23)}$ we learn that nature is not only beautiful and bountiful, but also dangerous. The widow's husband and daughter were buried alive by the dunes. The villagers have "recruited" the entomologist as one of a succession of "helpers" who must help continuously dig out the houses in the pits from the sand constantly threatening to engulf them. (No one is named except for the entomologist, and then only in the final "Missing Person's Report." But I will refer to him throughout as Niki).

No sooner has he sat down to eat with the widow than he gets into an argument about whether or not sand can attract water. This becomes an organizing principle of the film. Niki argues with the widow when she puts an umbrella over him as he eats her food. "The sand seeps in," she tells him. The words take on great symbolic weight as the film develops: that line is a commentary on everything that the man will experience about life in the dunes. Sand seeps not only into food and clothing and skin but into the very consciousness of all who live in the dunes.

Niki professes to enjoy "local delicacies," but he resists local knowledge, imagining that his "scientific knowledge" is superior. He imagines that the problem with the sand raining down on their heads must be with a damaged roof. "No, it's the same with newly thatched roofs," the woman explains. After he has argued with her about the type of insect that cause the initial damage, she goes on, in her soft tones, to explain that the bugs are not the worst of the problem: "even a beam this big will get spongy and rot," she says, holding her hands apart. How? From the sand. How so? "I guess it draws moisture." He calls this "nonsense. Sand is naturally dry."

"But it really makes things rot." "Use your common sense," he snaps. As he derides the experiential knowledge of the woman, he hands his bowl back to her for a refill and continues: "A desert is dry because it's all sand. Have you ever heard of a damp desert?" So he has laid out what he thinks are both the common-sense and scientific perspectives: the properties of sand are its dryness, and that it is devoid of life. 
The visuals underscore a seeming subservience on the part of the woman, yet also the mild way in which she insists on her truth. She brings out a teapot covered in plastic, to keep out sand. After she replaces the covering, she repeats, gently but insistently: "But it does rot. They say if you leave sand on clogs, they'll rot in two weeks." Niki laughs, and chokes on an indigestible fact. "That's ridiculous." The woman also laughs, but continues: "The wood rots, and so does the sand. We found soil in the ceiling of a buried house rich enough to grow cucumbers in." Niki is again dismissive, in the way that one treats people whose delusions are beyond reach. "Okay, whatever you say." After he finishes, he moves the umbrella, and sand descends, as if to rebuke him. The woman continues with her ongoing commentary about how the sand has a life of its own: "When it's windy, two feet of sand can pile up in one night."

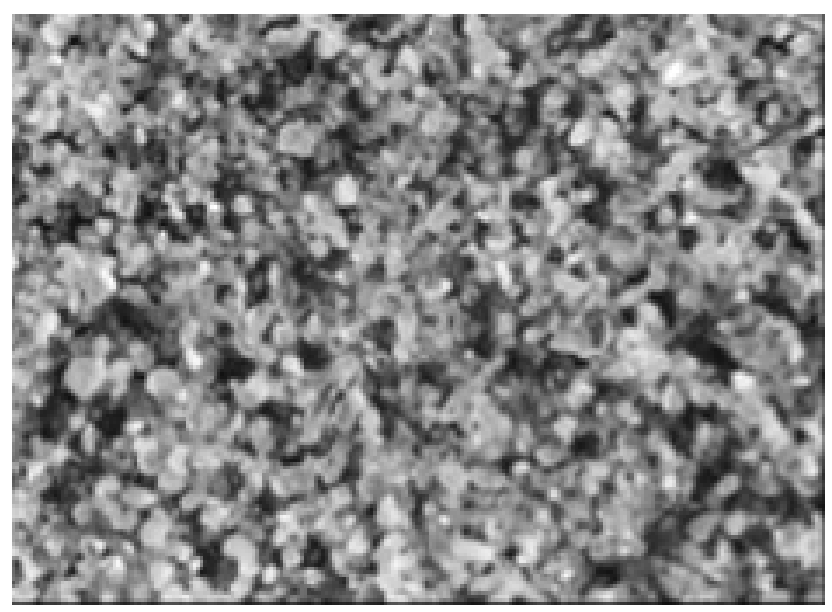

Figure 4:

The visual narrative continues to illustrate how Niki is deeply invested in his particular form of scientific objectivism. There is an extreme close-up of him pushing a pin through a beetle, and then adding it to his collection on Styrofoam board inside a box. As such images return, as a motif, we come to understand that this is a visual metaphor for Niki's relationship to life: he likes to pin things down. But he himself is pinned down by his attitude. This is "a man whose behaviour betrays his insecurity," Audie Bock notes, as in "his irritating need to dominant or be right when talking to a woman."(24)

Before being offered shelter by the villagers, while asleep in a beached boat, Niki remembered a Tokyo woman who criticized him for arguing too much. "But the facts speak for themselves," he concluded. However, her image is superimposed on the sand, an early indication that the sand will "rub off" his sense of superiority to women, and his sense of distance from/control over nature, which are of course interrelated.

Although the woman on the dunes, who Abe apparently intended to be a sort of anti-geisha, ${ }^{(25)}$ is too servantlike to directly challenge her guest's argumentative nature, she continues to school him. After dinner, when she brings in his bedding, she continues with her argument: "See? Even the futon is damp." And she continues to teach him about the sand's character, in a way that emphasizes both its power, and its relationship to water. "Last year a storm swallowed up my husband and daughter....The sand roared down like a waterfall." When the lamp goes out, she immediately says: "It's the sand." That is, sand attracts water, a fundamental reality of her existence that she continues to underscore, in manners both direct and indirect.

When Niki goes outside the first night to watch her shovel, he asks if she always works at night. "Yes, the sand's moist." She instructs him about the value of community life. "This village has real local spirit," she tells him. He is both uncomprehending, and then dismissive. "What kind of spirit?" he asks with a perplexed, then sarcastic look. "Love of our birthplace," she explains. The biggest imperative is survival: "The sand won't wait," the widow says, having already shown how literally true this is, with the story of "waterfall of sand." Shovelling the sand is truly a labour of Sisyphus. And it is only the love of birthplace, and the community spirit, which ennobles this seemingly pointless labour, in the view of the woman.

\section{Visual Motifs}


Chapter 7 ("Escape") begins with a closeup of Niki's watch, when he awakens and can't leave because the rope ladder has been removed. I wish to call attention to three recurring visual motifs which provide important cues for the film's narrative, and meta-narrative:

1) Time (it ends when he misses his bus. His watch stops working)

2) Entrapment - both pinning and encasing insects, but also Niki framed through "bars" or windows, or shot from a distance as if he were the insect.

3) Eyes and observation: binoculars; crow's eyes, etc.

The "sands of time" impose their own sense of time. At times we see flows like the sands of an hourglass, but the movement of the sands seems quite foreign to clock-time. Predictably, Niki's watch ceases to function after a few days in the sand. When he falls into a sleep-trance in the abandoned, sand-filled boat on the beach, he is entering a sort of dream time. Although Niki will often protest to the woman that he is a respected professional, and that he can't "dally" or waste time, his sense of time will be reconstructed during his time in the sand dunes.

The visual motif of entrapment is reinforced in a variety of ways. At times we see the point of view of the villagers, who look down on Niki as if he were one of the insects that he confines in a vial. They experiment on him, as he experiments on his insects. Both believe this entrapment serves a greater good: science, or the survival of the community.
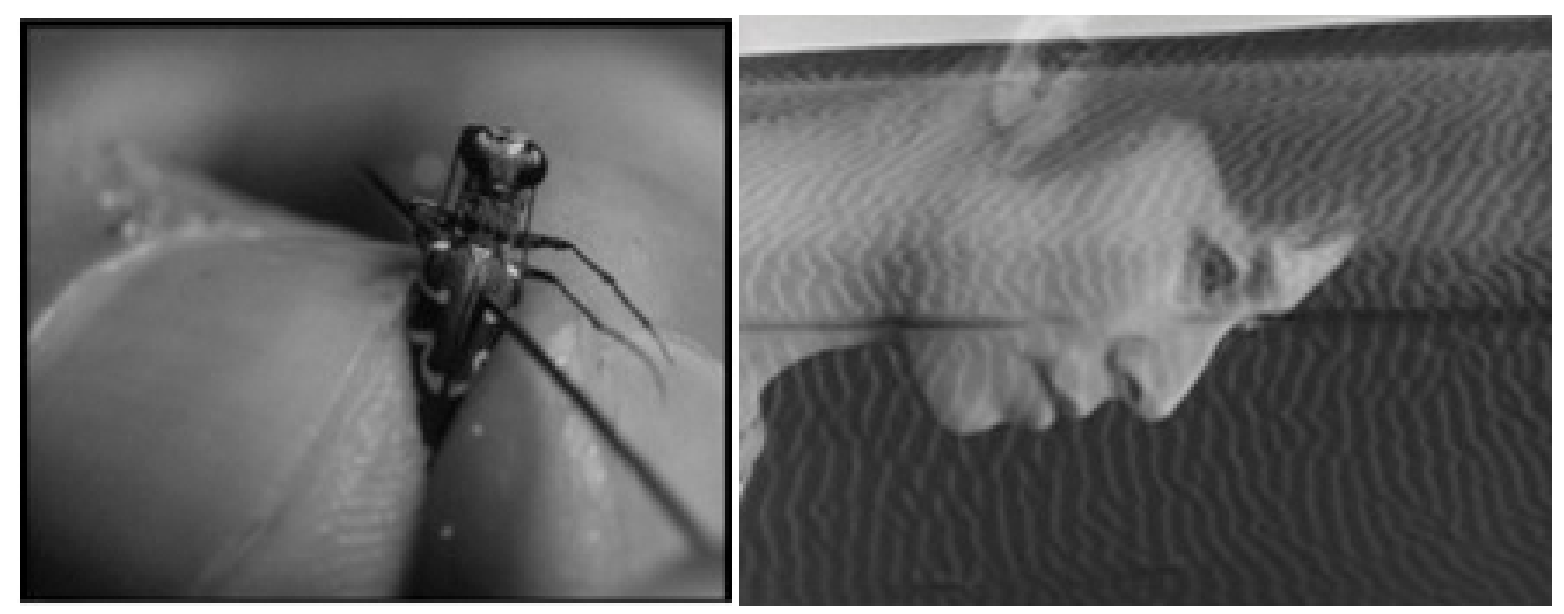

Figure 5:

He literally binds the woman to attempt to force the villagers to free him, but this only serves to reinforce the apparently finality of his bondage: above all, because they can withhold water, the ultimate power and discipline in this environment. Although the early framing tends to be of a rather literal sort of "behind bars" imprisonment, this shifts towards the ends. One memorable shot is from outside, through a small woodframed window about the size of a prison window, and shows Niki looking out another window, towards the crows, which he has imagined as his means of escape. But this shot shows a particularly meditative Niki. One is put in mind of a long history of visionaries who attained second sight while in prison. In this very scene Niki "catches water," and discovers new definitions of freedom.

The visual narrative about sight, and Niki's efforts to see (correct his myopia), is creative. Some of the earliest iconic images of sight, or eyes, are quite Foucaultian. Immediately after Niki unbinds the woman, we see a man up on the rim of the pit, looking down with binoculars. This reinforces the limits of Niki's ability to achieve freedom through force, or define the terms of his existence as a "helper" in the sand pit.

But the motif of sight is revisited repeatedly. That first morning, he rubs his eyes, trying to make sense of the nude female body sleeping in front of him. ${ }^{(26)}$ Niki cannot make sense of what he sees. We see his eyes superimposed upon the curve of the woman's waist and hip, and then in a match cut we see the woman's 

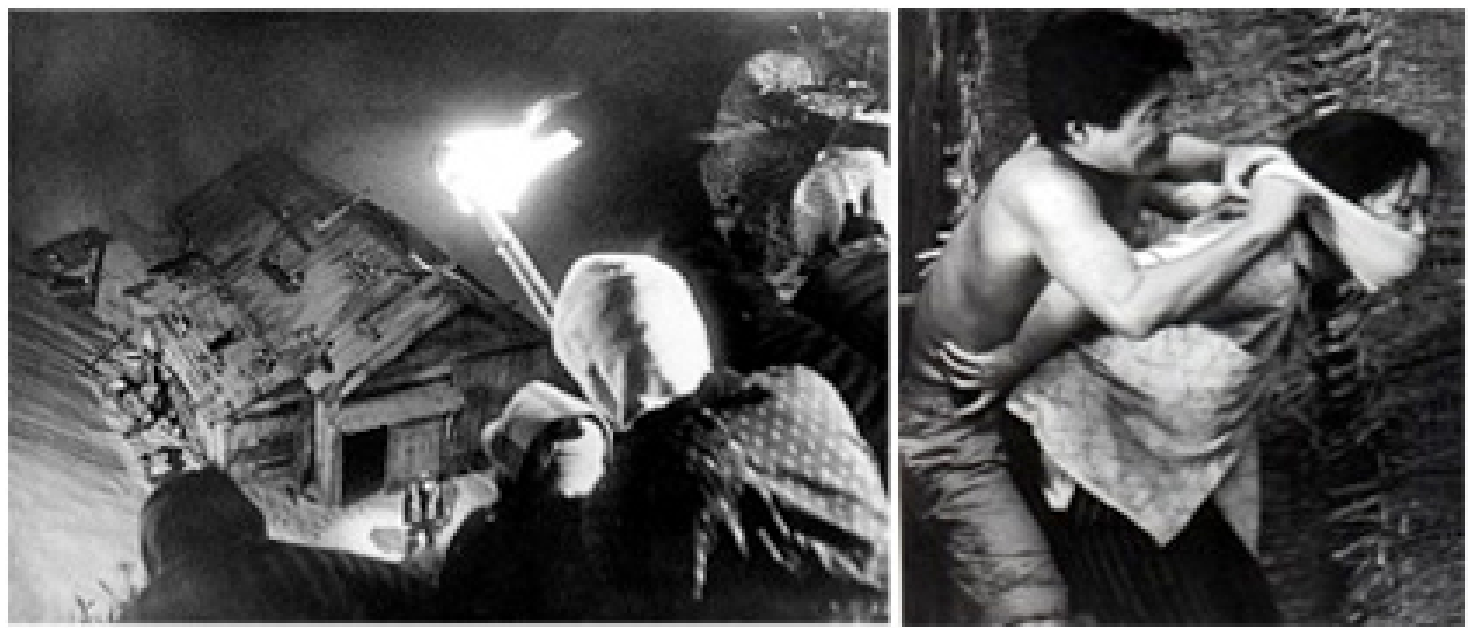

Figure 6:

curves superimposed on the natural curves of the sand dunes. Sand is already seeping into his consciousness. Later in the film, Niki puts eye-drops in his eyes, trying to clear his vision in both literal and figurative ways.
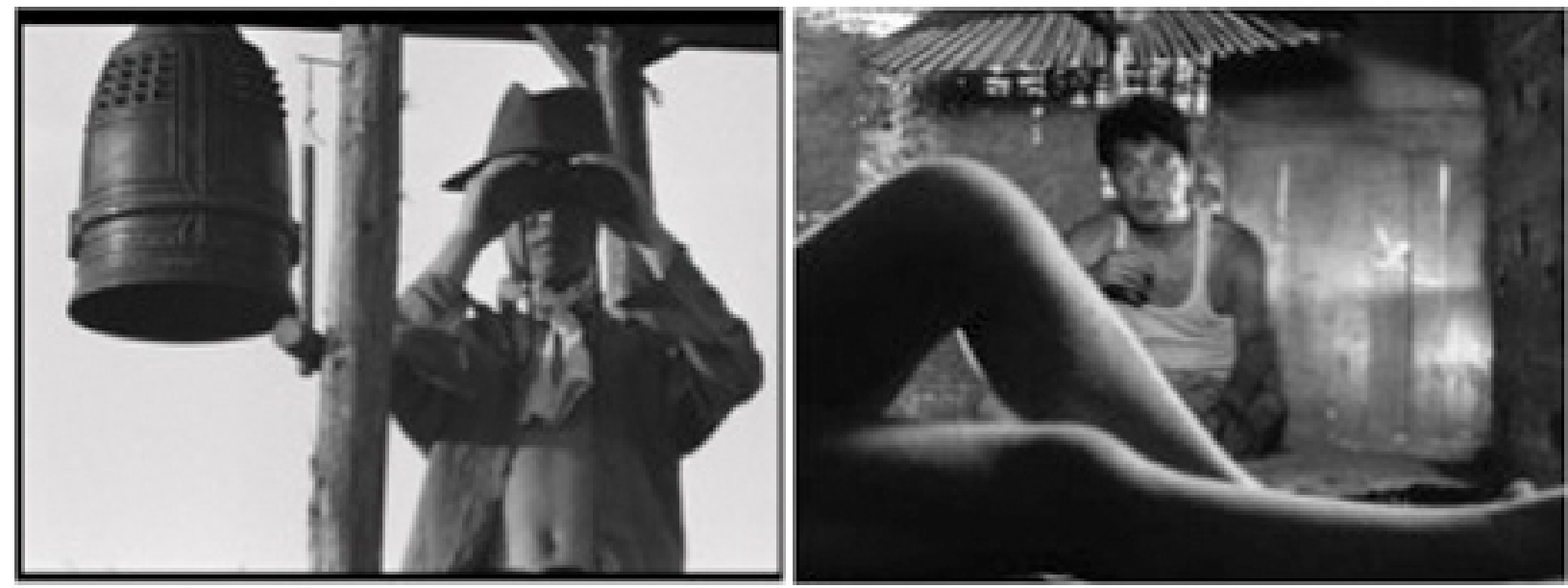

Figure 7:

Water is the most important element in his coming-to-vision, although always in relationship with the sand. In the beginning, his unwilling education about the mystery of water in the midst of dry sand comes through the agency of the woman. Just before he binds and gags her, she has told him: "You shouldn't wear anything in bed...You'll get rashes from the sand....The sand draws moisture" (my emphasis).

In Chapter 16 ("Diversions"), when plotting an escape, he asks for some scissors, which turn out to be rusted. "It's because of the sand." The implication is clear: once more she is telling him that this is because sand attracts moisture. The potential brutality of that relationship will shortly become crystal clear when, during his attempted escape, Niki becomes trapped in quicksand - in the low places where the sand is able to attract a particularly lethal concentration of water.

\section{Interface Between Sand And Skin}

Niki arrives in the world of the dunes thinking, with the "second nature" of the anti-natural man, that nature and humanity are separate. But the doors of perception are opened to inter-relationships that had been previously invisible, or seemed impossible, not only sand's ability to attract water, but also the interpenetration of sand and skin. 
After Niki discovers that he has been held captive, his "captor" explains her logic both in terms of human need, and community obligation. She apologizes: "this life's really too hard for a woman alone." The she moves the discussion to the sand, and community. "The north winds will come soon. There may be sandstorms too...If I fall behind, my house will be buried...Then the house next door would be next." This inter-connectedness - of sand and skin, of man and woman, of individual house and the community - is visualized in Chapters 11-13. Chapter 11 ("Suffering") begins with the image of a moth trapped inside a glass lamp globe - symbolizing what Niki has imposed on the woman, but also conditions he is creating for him self, by not allowing the labour necessary in order to receive water. "If I suffer, you suffer," he tells her. But the true nature of the suffering both will have to endure is signalled by more shots of sand falling, looking by turns like an avalanche of snowy- sand, or sand that "roars down like a waterfall."
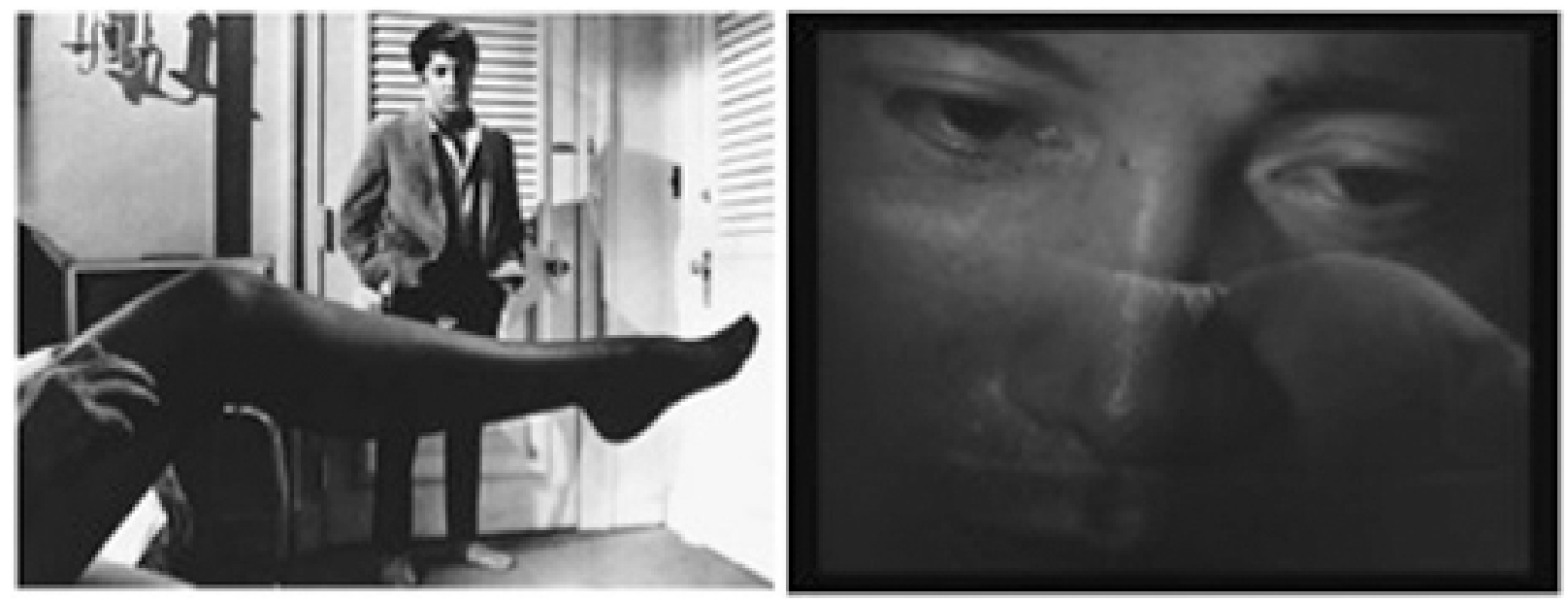

Figure 8:

As Wimal Dissanayake has observed: "The central trope in the film...is sand. It is at once beautiful and frightening, attractive and repulsive." ${ }^{(27)}$ The beauty is inescapable in the artistic sensibility with which Teshigahara and cinematographer Hiroshi Segawa have framed (and of course reconstructed) ${ }^{(28)}$ the sand. The fright, indeed the horror, was evident on the faces of both Niki and the woman when he tried to dig his way out, and unleashed another avalanche/waterfall which almost buried him. Teshigahara's mise en scene here seems to be an homage visual horror we have seen in various science fiction films, when a man or woman is overpowered by an over-sized "monster" or force of nature.
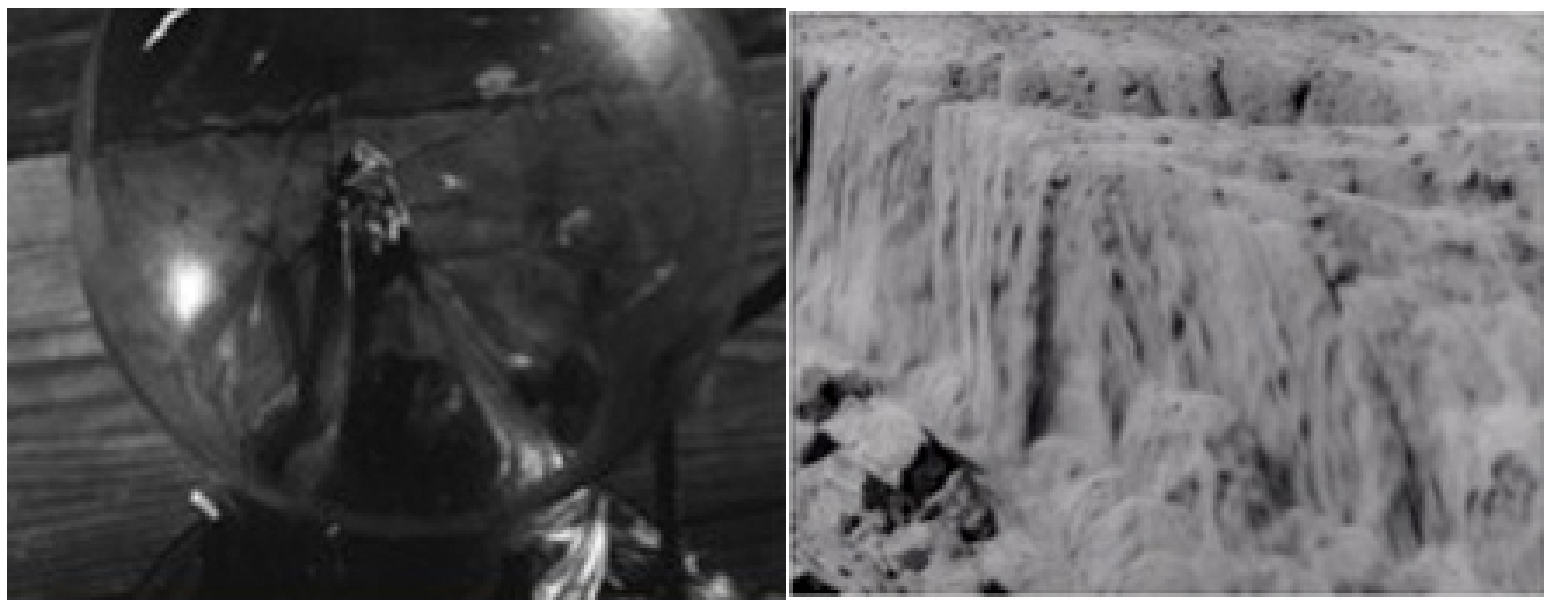

Figure 9:

But the scenes in which the sand overwhelms Niki and the woman seem to bring them closer in the flesh. 
After Niki is buried following his first escape attempt, the woman wipes the sand off his back, and we get a growing sense of the "attraction and repulsion" between them.

The consequences of sand-on-flesh when an absence of labour has led the sand to build up, and water to disappear, are dramatized in a visual narrative which often takes place at an almost microscopic level. Chapter 12 ("Ideas") opens with a close-up of about two square inches of the woman's face, including only her eyes to the bridge of her nose. The tiny grains of sand in her hair and on her flesh are immediately apparent. The camera creeps down and then right, revealing the dryness of her lips, and then to her neck. Her sweaty skin has become a monumental mosaic, grains of sand imbedded in skin pores. The rasping of the soundtrack reinforces the impression that we are seeing a potentially lethal agony.

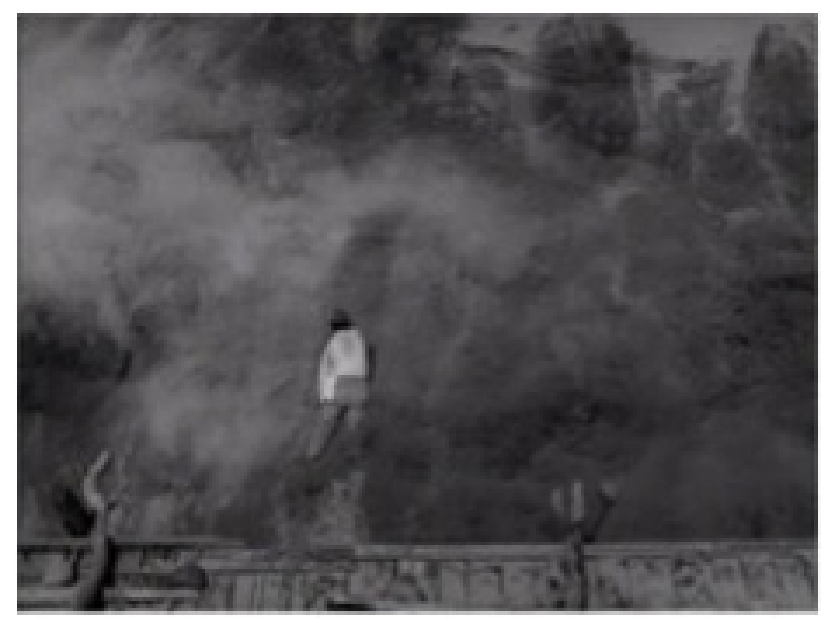

Figure 10:

Outside Niki urinates into a bank of sand that has already covered half of the woman's shack. He shadowboxes: still Sisyphus rebelling. His fighting spirit is alive, but nature mocks his citified bravery. The house lurches and sand pours through the cracks in the roof. "Run for it!" Niki yells. The wood structure of the house creaks, clearly close to collapse. An extreme close-up of two of the woman's fingers holding chopsticks reveals even further just how fully sand has penetrated into their skin. A dialogue between the man and woman transpires while the camera lingers over the sand on her hand. "Can't we do anything about it?" he asks. She tells him what is self-evident: "It's because we haven't shovelled any sand for two nights." Sisyphus must put his shoulder to the boulder. But Niki still imagines that water is unconnected to sand. "Water!" he yells at her. "I'm talking about water! Aren't you thirsty?"

With the camera still caressing her sandy hands, the woman responds: "if we just started working again..." But the man still feels like a victim, and clings to a "scientific" perspective. The camera runs across his throat now, also covered by sand, also gulping. But even while in danger of death by dehydration (dig or die), he veers into a semi-hallucinatory state, fantasizing about some rational way to "Make the sand work for you, not against you."

Chapter 13 ("Sand") opens with a shot of the woman's eye which almost completely fills the screen. The grains of sand in her hair are even more amplified, along with sounds. Along with something like a dry rattle, we hear the equivalent of a creaky door opening, as the woman's eye fully opens. The sound and visuals signal that we are moving into a more elemental reality.

This move into the realm of instinct, and the senses, is underscored when we follow her line of vision to the eyes of the man, suddenly turning to the shochu (liquor) that the villagers have left. The shot of Niki's hard, squinting eyes and his sand-caked face looks like a referent for the iconic close-ups of Clint Eastwood in spaghetti westerns. The visual narrative seems to be: "desperate times call for desperate measures."

After setting his mouth on fire with liquor, Niki bemoans how "futile" and "hopeless" resistance to the sand is. His tone and attitude seen hysterical, but his discourse is also "realistic": he has recognized the 


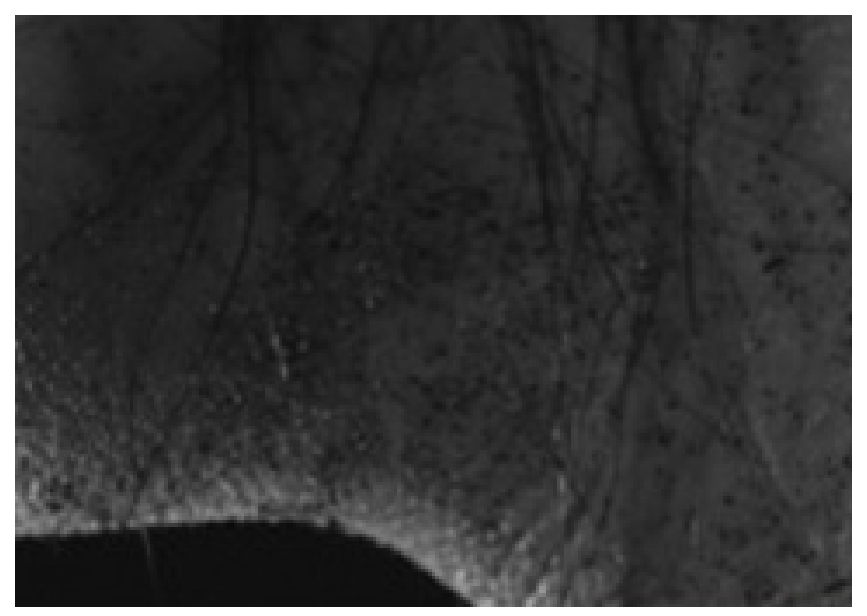

Figure 11:

power and indeed the volition of the sand. "If it wanted to," he muses, "the sand could swallow up cities, even countries." Beginning with his hand on the sand-covered wooden floor, the camera slowly moves up his sand-covered arms, on which he leans, and up to his face, conveying his monumental presence, like Sphinx in the desert. His words reinforce that impression, and the logic of his recognition of the power of sand to dwarf and indeed to swallow human beings. "A Roman town called Sabrata, and that one in The Rubaiyat of Omar Khayyam. Both completely buried under particles an eighth of a millimetre wide."

In half-drunken rage, Niki grabs a shovel and tries to dismantle a wall, hoping to construct a ladder. In the struggle between man and woman, his hand comes to rest on her breast. Much of the sexual heat is generated by the process of his brushing sand off her. The sand that had come between them now unites them. It becomes impossible to see a full separation, because the sand that still covers them is like a third skin they share. As they slide into lovemaking, the soundtrack reinforces the sense that they are sliding together into the sand. The inter-melting and release is signified by the last shot of this chapter, the slow orgasmic flow of sand, and the first shot of Chapter 14 ("Visions), a crow flying.

In this post-lovemaking chapter, as soon as Niki awakens, he begins to hallucinate the flow of water. To his cry of desperation, the woman appears like an angel, in her kimono, her hair down, in front of a window: "You see, if we just started working again..." And the man gives in to the power of the woman, and of the sand: he will play his Sisyphean role. But he is dangerously dehydrated. As he slides into unconsciousness, a deeper level of his being glimpses the truth of what the woman has tried to tell him. We see (through the filmic representation of sand and water having penetrated his unconscious) water bubbling up from the sand, almost like oil rising to the surface. The gurgling becomes a clear stream over a sandy creek. The camera holds the image of the surface of the water. Then we see slow motion drops of water falling from a leaf, a foreshadowing of the water pump that the man will accidentally "invent."

\section{The Limits Of Scientific Objectivity: Catching Water}

"Myths are made for the imagination to breathe life into them," Camus wrote. ${ }^{(29)}$ Abe and Teshigahara animate Camus' version of the Sisyphus myth by recasting the arrogance for which their Sisyphus is being punished as a rigid form of scientific objectivism. They "redeem" him by sending him into nature where he is forced to recognize the limits of his "anti-natural" version of science. But he finds meaning in his Sisyphean labour not by rejecting science, but by applying the scientific method to living processes rather than the study of dead objects, and by dedicating the benefits of his new, more "feminized" knowledge, to his family and community.

It is telling that in the "Sand" chapter, Niki uses the words "futile" and "hopeless" to describe his impotence faced with the sand's power. The gods imagined that there was "no more dreadful punishment than futile and hopeless labour," Camus wrote. And they directed their most dreaded punishment against this King of Corinth because of his hubris: "he is accused of a certain levity in regard to the gods. He stole their 
secrets...[he] put Death in chains."(30)

Cruelty to humans alone is not of sufficient gravity to warrant a life of meaningless sacrifice, which has long been the greatest fear of would-be heroes, as Che Guevara once wrote as a young man. ${ }^{(31)}$ No, his unforgivable hubris was in relation to the gods. He went beyond his station by imagining himself a "peer of the Gods" who had the right to report on Zeus' sexual indiscretions. Hence, many interpretations of the myth have focused on mortal man being forced to recognize the limits of his ambition and vision. For Lucretius, Sisyphus personified politicians who come to realize that the quest for power is an "empty thing." Welcker believed that the myth was a symbolic representation of the vanity of the human quest for ultimate knowledge. ${ }^{(32)}$

Niki's quest for knowledge is vain indeed: he wants to see his name in a guide book. His hubris is evident in his myopic belief that his scientific world view, attained through killing living creatures and "pinning" them in a system of classification, is superior to the knowledge of people who actually live in nature, rather than merely studying its dead relics.

In "Captivity," Niki declares the woman's labour to be an incomprehensible "self-sacrifice." "Let them deal with the sand scientifically," he urges. He has lost control, but he still believes that as a "scientific man," he has "the upper hand." The beginning of Chapter 10 ("Rations"), begins with a shot of three vials containing insects, one broken. We hear his voice declaring "There's nothing to fear" (or "Why should I be nervous"). But again the visuals cue us: his comment about having the "upper hand" is delivered as the camera pans to him pinning insects. He keeps fear, or his nerves, at bay through retaining his distance from (and delusion of control over) actual life. His scientific world view keeps him "sealed off" from nature.

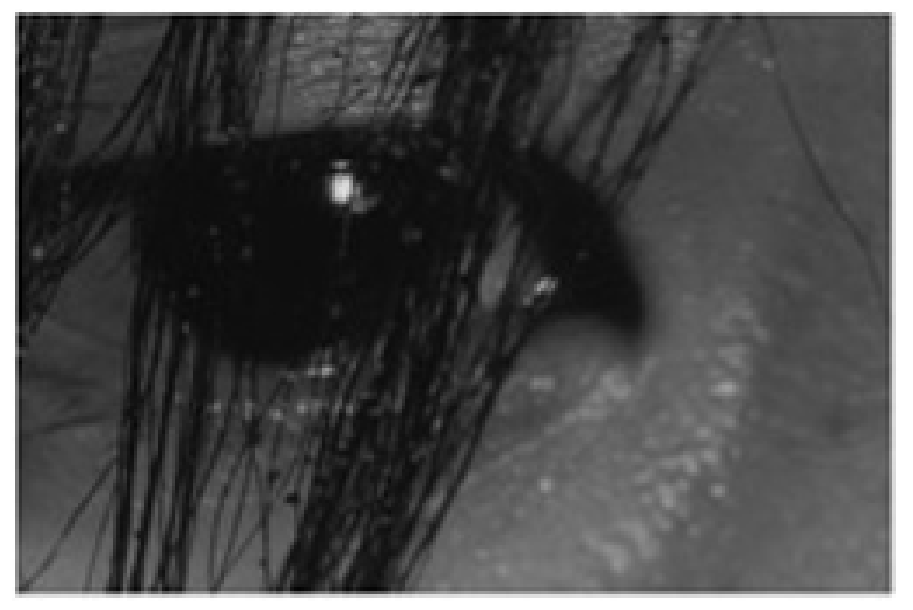

Figure 12:

However, the limits of Niki's practical knowledge are visually burlesqued. He stumbles and bump into things; he brings down suffering on his head. He almost falls into the pit twice before being lowered into it; climbing down the rope ladder, he falls the last 5-6 feet. He bumps into the woman's umbrella. He bumps into the window as he shakes the sand out of his clothes. During his momentarily successful escape, he bumps into a village woman, thus setting the dogs to barking at him and alerting all the villagers to his presence.

In "Ideas," while becoming delirious with thirst, Nike describes himself as "a teacher, and something of a scholar," and still believes that he is "the right man for the right job" in order to "make the sand work for you." Clearly, his ideas are still rigid. When he tried to "scientifically" dig his way to freedom ("It's not impossible. I'm going with the natural slope of the sand"), the "sand roared down like a waterfall."

But his descent into unconsciousness, and the vision of water gurgling up from the sand, foreshadows how he begins to move towards a different sort of knowledge. He will not stop being a scientist; but he begins to incorporate other forms of knowledge. He looks more closely, and begins to see "the world in a grain of sand." 
When the villagers first lower Niki in the pit, they warn him: "Don't look up, or you'll get sand in your eyes." Literally, they are telling him how to adjust to life in the pit. On another level, this reinforces Abe's description of the world view of the entomologist as being limited to three square feet around his feet. But on a deeper level, this points towards a process by which Niki eventually learns to see, by looking down even further.

The achieving of freedom through better vision, and a more complete scientific knowledge, is a developmental process. Niki recognizes that his ill-fated flight towards freedom was an "utter failure" because he "should have known the geography." A key transitional moment occurs in Chapter 20 ("Three Months"), which starts with yet another image of Niki's insect collection. But he now has a different catch in mind: crows. When he describes his crow trap as his "last hope" (he hopes to tie a message to the captured crow), the woman smiles at him as if he were a cute, foolish child. "Crows are very clever," she tells him. Although he is still understandably resisting his captivity, his very dress - a traditional Japanese coat - indicates that he is beginning to accommodate.

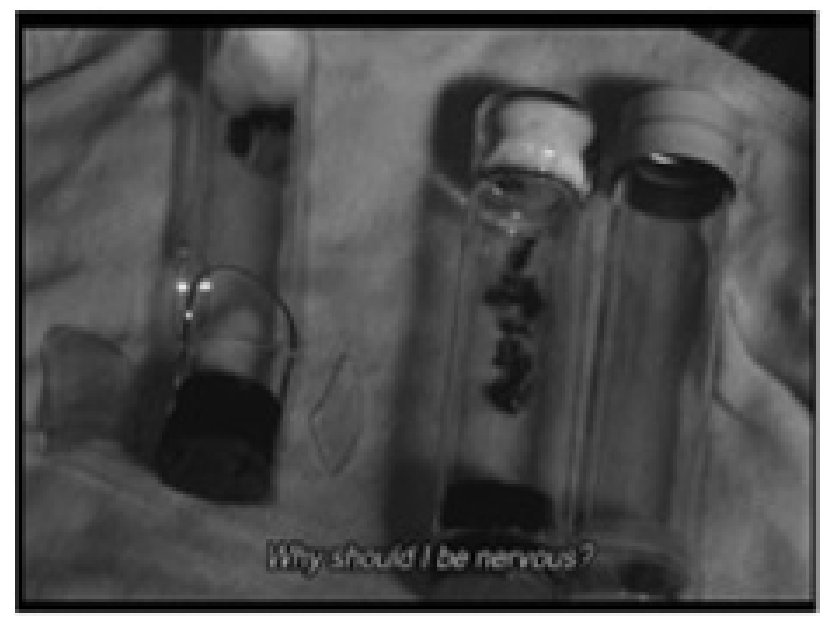

Figure 13:

Once again, the woman proves to be right. Although Niki dreams of escape, he is beginning to see things the woman's way, which shortly includes a seemingly sudden realization of his willingness to sacrifice for her. A pivotal scene of symbolic power (Chapter 21, "Business") opens with Niki applying eye drops. Now almost half a year from his capture, in the dead of winter, he is still trying to "see" more clearly, to become accustomed to life in the sand.

The woman is doing bead-work in order to raise funds to buy a radio. He laughs at a cartoon about a man who has been flattened by a steam-roller, and says "I keep smiling through thick and thin." The man and woman laugh together much like a couple. But then Niki, remembering that he too has been "flattened," knocks the woman's bead-work onto the sand. He devalues the two things that probably are most important to her: the radio, symbolizing her willingness to sacrifice for his relative happiness, and her community. "What good's a radio? Soon it'll be too late. People only care about themselves...Before you know it, they'll abandon us here."

"Never! All the sand is here!" she responds with great conviction. Niki feels compelled to shock her into an awareness of her virtual slavery. "The sand? What good is that? It's the source of all your troubles." Their ensuing dialogue reveals a deeper truth about the nature of the sand-human relationship. She reveals that they sell the salty sand illegally. But she is un-concerned about "other people's business. Somehow, her confession seems to humanize the woman to Niki. He seems to recognize how uncouth his behaviour has been. Although he does not apologize, he begins to help her pick up the scattered beads, and to sift the sand into which they have fallen.

After Niki realizes that both of their dreams result in "rigid thinking" (he wants "to go home"; she wants happiness in the sand pit), he reflects: "Even if it's only a lie, it helps to have hope, that tomorrow things 
will change." During his words, the camera shows their hands putting sand in the sifter, and the beads reappearing. This seems to indicate that their work has in fact become a joint project, and that Niki's words about keeping hope alive apply to them both.

The woman confesses her deepest fear, that "when I go to sleep, that I'll wake up alone again." After musing on this, Niki get up and returns with his insect collection, tosses the insects and bags into the fire, and gives her the boxes. "Put them in here." A close-up shows the insects beginning to catch fire. The understated symbolic power is dramatic: Niki has suddenly sacrificed what is most precious to him, what had given hope and meaning to his life, the very core of his identity, "even if it's only a lie." Perhaps he recognizes the vanity of his hope at that moment. The woman's confession of fear makes him decide to cast his lot with her.

This is a key moment in the process by which Niki moves towards new vision by jettisoning things that had previously defined him - and blinded him. As Patricia Erens writes: Niki's "progress can be gauged by what he gives up - his flask, his camera, his watch, his insect collection, his western clothing, and finally his desire to leave. His gains are emotional involvement, social commitment, and spiritual freedom...." (33)

Niki's "social commitment" begins to come into focus in Chapter 23 ("Water"), when he discovers for the first time that his "crow trap" is actually a water pump. This chapter begins with the image of a crow's eye, and then a shot of a group of crows on fences. The clever crows are outside, and not in his trap. In winter, Nike wears a traditional jacket. When he looks into the bucket and sees water, Teshigahara does a reverse angle shot from the water's point of view - looking up from the bottom of the bucket. As a look of astonishment grows, Niki rips the paper away, and draws closer. The next shot looks down into the reflection of his face in the water. Then we return to the water's point of view, the man's face serious, taking in the implications of his "discovery."

Niki touches the water, wondering how it could appear without rain. "It must be capillary action." In closeup: "If I can perfect the technique, we'll never worry about water again." The shift to the plural WE is significant. Back inside, shot in a mirror, we see his "Eureka" gestures of pure exaltation. Niki still wants some glory, but the thought of his scientific expertise is immediately applied to a social context. The camera then shows him diagramming the pump's capillary action, while he narrates: "The entire dune acts as a pump...It's as if we're sitting on top of a suction pump." The "we" again clearly signals that Niki's thinking about the dune and those who live on it is shifting, as he recognizes what his woman had tried to tell him all along. ${ }^{(34)}$

Camus chose to focus on what Sisyphus "thinks of during his descent...It is during this return, that pause, that Sisyphus interests me." (35) When the rock has rolled back down the hill, Sisyphus has time to meditate on the existential meaning of his "futile and hopeless labour." In a similar way, I am interested in Sisyphus in the sand pit at the moment when he looks into the bucket and sees his face reflected in "miraculous" water. Does he at that moment think, my God, the woman was right? His discovery that sand does attract water defies but also redefines his prior "scientific" article of faith about sand and water as mutually exclusive elements.

During his time in this sandy wilderness, Niki's scientific mindset is re-directed. Rather than only being good for "catching insects by the tail," and being defined by a paper trail which "pins" him in relation to women and society, he "catches water" - i.e. a Zen-like activity which can benefit an entire community. When Niki looks into the depths of a hole in the earth in the bottom of the sand pit (also the woman's "hole"), as metanarrative he is looking into the dwelling place of the Tao. When the camera assumes the position of the Tao (the water in the low place), it is able to reveal a moment of transfiguration in Niki's face: the recognition that he is looking at a something like miracle - a "scientific mystery" that is perhaps the source of all life. The anti-natural man has discovered the secret of the dune, and in it a new identity.

\section{Thinking Like A Dune}

In Woman in the Dunes, Abe wrote: "The change in the sand corresponded to a change in himself. Perhaps, along with the water in the sand, he had found a new self." ${ }^{(36)}$ This "new self" does not become fully evident until the richly suggestive conclusion (Chapter 26, "Ocean").

Writers about ecosystems often reflect on how they came to an awareness of being part of a "greater community of life." In Aldo Leopold's essay "Thinking Like a Mountain," while watching the "fierce green fire dying" 
in the eyes of a wolf, he came to understand just what thinking like a mountain entailed: becoming aware of the balance of an ecosystem, and living within that balance, required a decentering of human desires. ${ }^{(37)}$

By the end of the film, Niki has begun to think like a sand dune. In the water he glimpses a broader set of obligations. This challenges his attitudes towards animals, and towards the villagers. Niki's remarks on animals throughout the film have been uniformly derogatory, and are in marked contrast to the perspective voiced by the woman and the villagers. After Niki ties up the woman, he tells her: "Men aren't dogs. You can't put them on a leash." When she enthuses about the jumbo crops that the Youth League has grown in the sand, Nike barks: "Even a monkey could be trained to do this work." As the woman repeats "a monkey," her facial expression is incredulous: she knows that these crops taken to an agricultural fair in Tokyo could only have been grown by humans working in close collaboration with the sand, the water it attracts, and the organic matter that is produced as a result.

After Niki poses his existential question: "Are you shoveling sand to live, or living to shovel sand," the woman gently derides the idea of "walking around aimlessly." He again explodes: "Even dogs go crazy chained up all day!" During another outburst when he scatters her beads, Niki declares: "I refuse to die like a dog." And when the villages propose that he have sex in front of them in exchange for the temporary freedom of getting to see the sea, he tells her, as he attempts to rape her: "Who cares? We're living like animals anyway."

The woman and the villagers view animals more respectfully. After they come to pull Niki out of the quicksand, one man says pointedly: "Even the dogs stay away" from the quicksand. Implicitly, dogs are more intelligent than Niki about the geography of the area. The same inference can be drawn from the woman's bemused comment that "Crows are very clever": they are not about to stumble into the jerryrigged trap of a city man like Niki.

Niki develops obligations to the villagers who saved his life: "we" enters his thinking. ${ }^{(38)}$ But these villagers are apparently willing to stoop to savagery and bestiality - to insist on a quid-pro-quo of "acting like an animal" in order to "glimpse freedom." But Teshigahara insisted that "Masks" showed Niki becoming part of the community. Perhaps it was a hazing ritual, and they knew he would not be able to do the deed. And the woman does in fact defeat him, physically. ${ }^{(39)}$

Niki's attitudes towards the woman, towards animals, and towards the villagers, undergo a transformation in Chapters 21-26. When he throws away his insect collection, he is engaging in a sort of symbolic act of animal liberation. The following chapter shows his capacity to humiliate himself and his woman, but this performance elevates him in the villagers' eyes. In Chapter 23, having foresworn any ambition to "catch crows," he now is thinking as part of a community. When the woman falls ill in Chapter 25, and Niki seeks assistance, the villagers congratulate him on finding she is pregnant. Niki rubs her, very much the concerned spouse, until other villagers arrive to lift her out. After they are gone, he discovers that the ladder has been left, and climbs out to look at the sea. When he returns, the first thing he does is to look again at his water trap.

Niki's transformation is not fully conscious. He is digesting things that are new to him - water in the bucket, a pregnancy, a means of escape. As a reformed hero we might want a definitive decision, but he has not had time for that closure. He does not express escape as a probability, just as a possible outcome. But what excites him at the moment is the prospect of sharing his discovery of the water with the villagers.

From a Coda, a Missing Persons Report written seven years after Niki disappeared, we can infer that he stayed in the dune. What we see as he looks into the water can be read with this probable outcome in mind. As the troubled surface begins to calm, he gazes into the water, and sees an object on the reflected rim of the pit. He looks up and sees a boy, peering down at him.

The clearing of vision has been a gradual process in this film, which anchors the visual narrative: Niki's use of eye drops; his unconscious visioning of water coming from the sand. In my reading, the moment when the water begins to still symbolizes a moment when Niki's mind has finally centred. And the instigator is precisely seeing the boy, first in the water, and then looking into his face. That boy centres Niki's mind, presumably, because he represents his son.

Niki's face signals the nature of vision achieved by this Sisyphus in the sand pit. A new warmth lights his 
eyes; his face is peaceful. There is a semi-quizzical expression, and a hint of a smile, as looks up at the boy. In that instant, he says to himself: "There's no need to run away just yet." His eyes drop to the bucket, and we see a light in his eyes that has never been there before: contemplation and a dawning of awareness. "Besides, I'm bursting with the desire to tell someone about the pump." Maybe "the day after tomorrow" he can think about leaving. But as the camera holds his eyes, it is obvious that he has much more on his mind than escaping.

I was struck by how much of "Ocean" is about seeing, or the emergence of vision. There are long takes of Niki gazing at the ocean. He watches the winter sun break through the clouds. He has so much things to say, ${ }^{(40)}$ but his experiences go beyond words. These apparently non-narrative "silences" are a necessary prelude, I think, to convey what a life-changing experience Niki is going through, and to prepare us for his revelation. Words which break silence acquire an unusual power. If we are expecting speech, or missing it, then the longer the wait, the greater the release tends to be, if the words are clearly shaped by the meditation which precedes them. ${ }^{(41)}$

Presumably the idea of fatherhood is entering Niki's consciousness while he gazes at the sea. When he returns to the pit, the pregnancy, and his socially useful "science project," seem to be dominant on his mind. But "going home" is a less pressing idea on a more distant horizon.

The weighted silence of this scene, and the focus on Niki's eyes, allows us to go back and re-read the "syntagmatic connotations" of that "eye in the dune" at the film's beginning. Film language seems to have a unique capacity to weight images with layers of meaning that grow in relation to what came before, and what comes after. New "meaning adheres to it because it is compared with other shots that we do see," James Monaco writes. ${ }^{(42)}$ The slow seepage of "droplets" of sand at the end of Chapter 13 and the crow flying at the opening of Chapter 14 would have little meaning in isolation. But after the prior lovemaking, with the eerie descending strings, the sand conveys a sense of the couple "turn[ing] into a liquid and melt[ing]," as Abe writes. ${ }^{(43)}$ The crow here is apparently a symbol of freedom or release, but other meanings "adhere" to it later.

The eye "lined by the sand" takes on an iconic quality in retrospect. Using the theory of syntagmatic connotation, with the Greek theoria as "a looking at, a contemplation," (44) we may look back and contemplate what this eye sees; what is the director's rhetorical purpose. I would suggest that the closing scene brings the film full-circle, indicating that this is the eye looking up from the womb of the earth. Hence the eye that once seemed confined or myopic has been cleansed and granted new vision, precisely by being rooted in the earth (the sand). The eye (Niki's initially myopic vision) has been "redeemed" by framing it in nature.

\section{The Eye That Blesses: The Woman In The Dunes And The Visual Turn}

I want to position Teshigahara's cinematic style in relation to a myopia sometimes evident regarding films that use visuals in a way that apparently "eschews or de-emphasizes stories and narratives." I use myopia in its broader definition, as "a lack of vision or foresight." Faced with a historical "downgrading of visual sense," theorists of visual narrative have argued that film in particular has the capacity to make sense of "logically insolvable problems," and that visual narratives are particularly well-suited to achieving insight or "overstanding" of "disordered, raw experience." ${ }^{(45)}$

Kelly Oliver has written an insightful analysis of a "view of vision as an alienating sense that separates us from the world." A telling example was Lacan's statement that he could find "no trace anywhere of a good eye, an eye that blesses." (46) This sense that vision curses, or imprisons (as in Foucault's panopticom) came to dominate film studies in the 1980s and 1990s, through Laura Mulvey and other Lacanian feminist film theorists who reified an all-powerful male "gaze." Some reacted to the perception that experimental film-makers had "repudiated narrative" by calling for a return to the primacy of word over image. ${ }^{(47)}$

Reacting against this pinning of film to the psychoanalytic couch, Al Razutis wrote in 1984: "There is no film theory, contemporary or otherwise, that is adequate to the needs of the many film avant-gardes." Contemporary film theory was aggressively logocentric, he argued, and thus unable to "adequately understand and theorize" experimental or avant-garde film practice. ${ }^{(48)}$

Seen in the long range or longue durée, such disputes may be a blip on the screen during a time in which "the image is returning to supremacy after the end of the era of the written word," as Sean Cubitt writes in 
Eco Media. But they also may arise out of a deeper iconophobia, reflecting the fear encoded in the second commandment that images will inevitably "take on a life of their own," as W. J. T. Mitchell has noted. Since constructing and to some degree worshipping images seems to be second nature for humans, religions and cultures of the word long sought to discipline and restrict this suspect tendency. ${ }^{(49)}$

The "iconic turn" represented by cinema's emergence is a forerunner of the "visual turn." From the beginning film aroused suspicions of its capacity to lead the masses into uncritical idolatry. However, the potential for visual narrative has long been apparent to film theorists. Béla Balázs argued that the close-up "revealed...the hidden mainsprings of a life which we had thought we already knew so well." ${ }^{(50)}$ He referred to psychological dimensions, the representation of which was a central concern of modernism. But the "identification" with a character through close-ups can also be applied to non-human subjects or characters, as Teshigahara demonstrated in Woman of the Dunes. WITD was a prescient classic which put an iconic nature in a privileged, and some would argue, liberatory position.

In a 2008 paper on "Visual Narrative Analysis," J. T. Page argues that while words tend to have rather fixed meanings, rules of grammar and syntax, "images escape these controls and stand in for a more complex reality" than linguistic discourse. Within the framework of my present analysis, visual narrative has an "unpinning" potential: "Visuals invite the viewer to participate in meaning construction."(51)

In the earlier parts of WITD, Niki had only seen objects. He was compelled to pin them into categories: "the facts speak for themselves." But his close encounters with the sand, the woman and the community restructured his gaze. Seeing this as a primarily positive outcome is of course not the only plausible interpretation. Timothy Iles has argued that the ending of this film is as bleak as 1984; that Niki has had his will to freedom crushed. ${ }^{(52)}$ I think this demonstrates the Procrustean nature of applying western notions of individualistic resistance to an Asian context. In any case, finding meaning within a context of confinement is a recurring trope of modernist and postmodernist fiction, as in the "freedom through serving a tiger while trapped on a life raft" in Life of Pi, or reclaiming the kitchen as a site of power in Like Water for Chocolate. ${ }^{(53)}$ Even if we admit of the central characters in WITD that "in truth they are slaves," there is also a long history of literature and film that centres on characters who carve out degrees of freedom even within bondage. ${ }^{(54)} \mathrm{I}$ believe it is too simple to read Niki's decision to "ignore" the ladder as evidence of submission to his bondage. In fact, at the film's under-stated but intensely climatic moment, we can surmise that Niki has experienced a form of both psychological and social liberation, because for the first time his vision includes "the look of love."

Understanding that such a look can be redemptive requires revisioning "the gaze." Drawing on Luce Irigaray's work, Kelly Oliver engages in such a reclamation project, when she proposes the "loving look as an alternative to the objectifying look." ${ }^{(55)}$ Looking into the water becomes for Niki something like Irigaray's prescription to "gaze together at the invisible." The surface of the water reveals previously invisible dimensions; he sees the inter-connectedness between sand and water, man and woman, individual and community. This vision is an eye that blesses. To say that love animates this recognition, and that the water in the womb of the earth is an eye that blesses is only an interpretation. But to return to Page's view, visuals invite this sort of participatory "meaning construction" by the viewer.

WITD gazes beyond a blind alley in which logocentrism removes us from nature. In "Ontology and Materialism in Film" (1976) Peter Wollen wrote: "The presence of language must signify, of course, the passage from nature to culture." "What raises us out of nature is the only thing whose nature we can know: language," Habermas argued. ${ }^{(56)}$ I don't imagine that either Wollen or Habermas thought that this movement out of nature and into culture was a bad thing. But for film-makers who seek to give expression to unconscious thought processes, or to revision the human-nature relationship, different concepts of language, culture, and narrative are needed.

Teshigahara is part of a cinematic tradition which, in centring visual narrative, seeks to expand and reinvigorate the tools of story-telling, and often to revision the human-nature relationship. Godfrey Reggio explained his move into non-verbal narrative as originating not from a "lack of love of the language" but from a conviction that "our language is in a state of vast humiliation. It no longer describes the world in which we live." Like Teshigahara in WITD, he felt that images and sound could represent this previously invisible world (the human-nature relationship) much better than devalued language. ${ }^{(57)}$ By "blowing up" 
first nature, Teshigahara was not only able to reveal nature's "life of its own," but also its power, as a character, to regenerate the second nature of humans.

Perhaps it is true that Niki simply decided to create a "better hole" rather than escaping the hole. ${ }^{(58)}$ But if the hole is read as the Great Mother, ${ }^{(59)}$ then clearly his decision to stay has made him whole, and has in fact resolved his crisis of masculinity. ${ }^{(60)}$

Once he is free to flee his captivity, Niki sees that this confinement, this discipline, has given him a new identity...so the papers of his false identities fall away. The Westernized Japanese man has found new meaning in a traditional Japanese village which lives on a sand dune which functions as a water pump. In choosing to remain there, he "goes native," and this is presented, by inference, as the solution to the existentialism of the "anti-natural man."
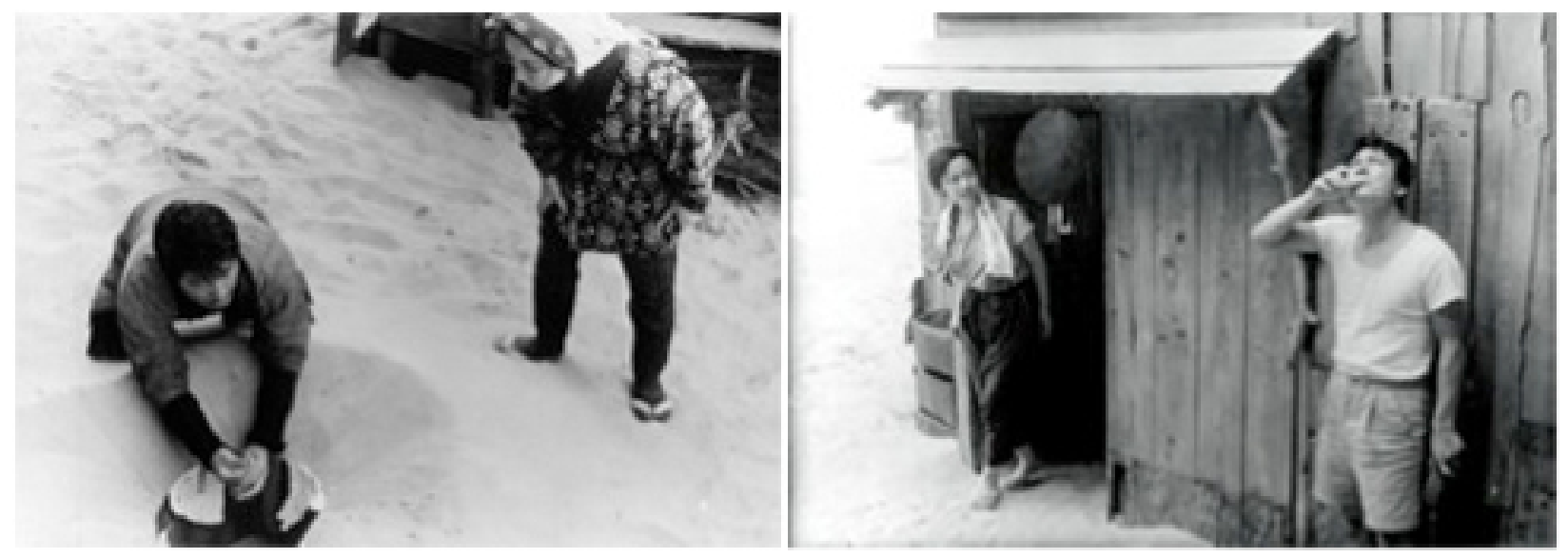

Figure 14:

\section{Notes}

1. Teshigahara in Peter Grilli, "The Spectral Landscape of Teshigahara, Abe, and Takemitsu," companion booklet to Three Films by Hiroshi Teshigahara (Criterion Collection, 2007), p. 10.

2. David Ingram, Green Screen: Environmentalism and Hollywood Cinema (University of Exeter Press, 2000/2004); Pat Brereton, Hollywood Utopia: Ecology in Contemporary American Cinema (Briston and Portland, OR: Intellect Books, 2005).

3. Timothy Corrigan and Patricia White, The Film Experience: An Introduction (Boston and New York: Bedford/St. Martin's, 2004). See Chapter 8, "Rituals, Conventions, Archetypes, and Formulas: Movie Genres," esp. $298 \mathrm{ff}$.

4. Westerns and the "quest into nature," Corrigan and White, The Film Experience, 203.

5. The title character of James Fenimore Cooper's The Pathfinder described the primeval forest of North America as "the true temple."

6. Luc Ferry, Le nouvel ordre écologique: L'arbre, l'animal et l'homme (Paris: Bernard Grasset, 1992), translated by Carol Volk, The New Ecological Order, (University of Chicago, 1995), xxviii.

7. John Storey, Inventing Popular Culture (London: Blackwell, 2003), ix.

8. Luc Ferry, The New Ecological Order, 5.

9. Through this after-life, icons often acquire mythic resonances. Icons are meta-symbols onto which audiences (icon-consumers) project their unconscious desires or fears. As people live through icons, over time 
icons accrue unlimited associations, taking on a symbolic character that may have little or nothing to do with the original referent.

10. Contemplative aspect, Corrigan and White, The Film Experience, 374.

11. Teshigahara on "images more than dialogue": from an interview in Max Tessier, Le cinema japonais au present: 1959-1984. It was translated from the French by Allison Dundy for the booklet included with Three Films by Hiroshi Teshigahara (Criterion Collection, 2007), p. 50.

12. Roger Ebert, "Review of Woman in the Dunes," Chicago Sun Times (February 1, 1998), my emphasis; http://rogerebert.suntimes.com/apps/pbcs.dll/article?AID=/19980201/REVIEWS08/401010314/1023.

13. High modernism, James Quandt, "Double vision," in Three Films by Hiroshi Teshigahara booklet (Criterion Collection, 2007), p. 38.

14. "Teshigahara and Abe," documentary in "The Supplements" DVD of Three Films by Hiroshi Teshigahara (Criterion Collection, 2007). Teshigahara cites French and Italian Neorealism as a formative influence in Max Tessier, Le cinema japonais au present: 1959-1984. Excerpted in Three Films by Hiroshi Teshigahara booklet (Criterion Collection, 2007), p. 48. Many principals in this adaptation were key players in post-war Japan's avant-garde art scene.

15. Periodization, Corrigan and White, The Film Experience, 352-62. Teshigahara was inspired by Italian neorealist emphases on "depicting postwar social crises" and "using a stark, realistic style clearly different from Hollywood's glossy entertainment formulas." Ibid, 371-2.

16. Audie Bock discusses "the new phenomenon in post-industrial Japan of ordinary people going missing, seemingly without provocation, never to be seen again." Because of the lack of privacy in Japan, "the impulse to drop out remains extremely powerful today." "Shifting Sands," p. 30. Teshigahara has elaborated on "the theme of disappearance" which was prevalent when he filmed WITD, and still continued: the sense of being closed in, he noted, caused some people "to run away...to find the freedom they are lacking." Max Tessier, "Interview with Hiroshi Teshigahara," in Three Films by Hiroshi Teshigahara booklet (Criterion Collection, 2007), 51.

17. Dennis Giles, "The Tao in Woman in the Dunes," Film Heritage (Spring 1966). Patricia Erens, Film Reference entry; http://www.filmreference.com/Films-Str-Th/Suna-No-Onna.html.

18. Giles, "The Tao in Woman in the Dunes," Film Heritage (New York), Spring 1966. James Quandt, Video essay, included in Three Films by Hiroshi Teshigahara booklet. See also Charlie Ahearn, "Teshigahara Zen and Now," in Interview, vol. 20, no. 8, August 1990.

19. Albert Camus, The Myth of Sisyphus and Other Essays (Knopf, 1955). 123.

20. Audie Bock, "Shifting Sands," in Three Films by Hiroshi Teshigahara booklet (Criterion Collection, 2007), 28.

21. Anton Bitel, "Review of Woman in the Dunes," Eye for Film;

http://www.eyeforfilm.co.uk/reviews.php?film_id=11848

22. Andy Beta, "Lust in the Dust and Japanese Drums," Oct. 26, 2007;

http://idolator.com/tunes/vhs-or-beta\%3F/lust-in-the-dust-and-japanese-drums-315513.php.

This seems similar to the collaboration between composer Philip Glass and cinematographer Ron Fricke in Godfrey Reggio's Koyanisqatsi.

23. This is a reference to Jean-Paul Sartre's play No Exit, one of several existentialist texts that influenced Abe. Among critics to pick up on this intertextuality, see Patricia Erens' analysis for Film Reference; http://www.filmreference.com/Films-Str-Th/Suna-No-Onna.html. See also Gilles Jacob, "Un Beckett nippon," in Cinéma (Paris), January 1965.

24. Audie Bock, "Shifting Sands," p. 30.

25. Joyce Hart, "Critical Essay on The Woman in the Dunes," in Novels for Students (Thomson Gale, 2006); 
http://www.novelguide.com/a/discover/nfs_0000_0022_0/nfs_0000_0022_0_00023.html.

26. The shot of Niki gazing at bent knee of the named woman seems to have been a source, or an intertextual reference, for this iconic shot in Mike Nichols' The Graduate, when the Dustin Hoffman character gazes at Mrs. Robinson in a similar pose.

27. Wimal Dissanayake, "Self, Place, and Body in The Woman in the Dunes: A Comparative Study of the Novel and the Film," in Literary Relations, East and West: Selected Essays, edited by Jean Toyama and Nobuko Ochner, University of Hawaii Press, 1990, pp. 41-54.

28. Teshigahara confessed that "I found it physically impossible to create an angle of more than 30 degrees" with the sand. Thus, much of the physical characteristics of the sand we see in the film are completely fictional, although of course they do "bring it to life" for human viewers in a way that would have been insufficiently dramatic, had Teshigahara limited himself to inclines of $30 \%$ or less. Ebert, "Review of Woman in the Dunes," Chicago Sun Times (February 1, 1998).

29. Albert Camus, The Myth of Sisyphus, 120.

30. Camus, Myth of Sisyphus, 119.

31. At about age 22, Che Guevara wrote in an autobiographical essay "Anguish": "To make a sterile sacrifice that does nothing to raise up a new life: that is anguish." Quoted in John Lee Anderson, Che Guevara: A Revolutionary Life (Grove, 1997), 69.

32. The sources I've drawn on for pre-Camus interpretations of Sisyphus include Edith Hamilton's Mythology: Timeless Tales of Gods and Heroes, 312-313, and the entry on Sisyphus in Wikipedia.

33. Patricia Erens, - http://www.filmreference.com/Films-Str-Th/Suna-No-Onna.html

34. The emphasis on an evolution towards a communal perspective is more pronounced in the film. In the novel Niki does not use the plural "we" when he first discovers water in the bucket: "It was just as if he were sitting on a suction pump." Abe, Woman in the Dunes, 234.

35. Camus, Myth of Sisyphus, 121.

36. Kobe Abe, The Woman in the Dunes (Knopf, 1964), 236.

37. Aldo Leopold, A Sand County Almanac (Oxford UP, 1987), 130.

38. While outside the pit on his ill-fated escape attempt, Niki mediated on the sense of obligation and even indebtedness he felt towards the woman, and to some degree, the villagers. Kobe Abe, The Woman in the Dunes, 186-193. While attempting the sexual performance for the villagers, Niki saw "so clearly they could have been himself. They were a part of him." Abe, 231.

39. Teshigahara on his intent in the "Masks" scene in the James Quandt video essay, on the Woman in the Dunes DVD of Three Films by Hiroshi Teshigahara (Criterion Collection, 2007).

40. Bob Marley, "So Much Things To Say," from Exodus (Island/Tuff Gong, 1977).

41. I explore the power of silence in "The Poetics of Indigenismo in Zapatista Discourse: Revisioning the Mexican Revolution through Mayan Eyes." (M.A. thesis, University of West Indies-Mona, 2008).

42. Syntagmatic connotation, James Monaco, chapter on "Denotative and Connotative Meaning," from How to Read a Film (Oxford UP, 2000), 163.

43. Abe, Woman in the Dunes, 232.

44. Corrigan \& White, The Film Experience, 419.

45. eschews, Corrigan \& White, The Film Experience, 260. Downgrading of visual sense, Sandra Moriarty and Gretchen Barbatsis, "From an Oak to a Stand of Aspen: Visual Communication Theory Mapped as Rhizome Analysis," Introduction to Handbook of Visual Communication: Theory, Methods, and Media, ed. Ken Smith, Sandra Moriarty, Gretchen Barbatsis, and Keith Kenney (Routledge, 2005). Logically insolvable, 
L. Gross, "Life vs. Art: The interpretation of visual narratives," Studies in Visual Communication, 4 (1985), 2-11 (quote p. 3). Raw experience, "Narrative Theory," in Handbook of Visual Communication, 346.

46. Kelly Oliver, "The Look of Love," Hypatia Volume 16, Number 3 (Summer 2001), pp. 56-78. Jacques Lacan, Four Fundamental concepts of psychoanalysis (Norton, 1981), 115.

47. Kaja Silverman, at the New Narrative Cinema and the Future of Film Theory conference, 9- 29-1983. Quoted in Al Razutis, "Menage a Trois: Contemporary Film Theory, New Narrative and the Avant-Garde," Opsis (Spring 1984). Razutis criticizes Silverman's "logocentric focus... which inherently define the imagistic and musical as 'not words." Teresa de Lauretis, "The Riddle of the Sphinx, Part II," also at the New Narrative Cinema and the Future of Film Theory conference. De Lauretis insisted that the avant-garde "can no longer deny narrative" and called for narrative-based film and theory that was "Oedipal with a vengeance," according to Razutis.

48. In "Menage a Trois: Contemporary Film Theory, New Narrative \& the Avant-Garde," Opsis (Spring 1984), Al Razutis criticized "Mulvey's often quoted and largely outdated essay" (note 3).

49. Fernand Braudel and Sara Matthews, On History (University of Chicago, 1982); Immanuel Wallerstein, ed., The Modern World-Systems in the Longue Durée (Paradigm Publishers, 2004). Sean Cubitt, Eco Media (Amsterdam: Rodopi, 2005), 27; Vilém Flusser, "Line and Surface," in Writings, ed. Andreas Stroh (University of Minnesota Press, 2002), 67. W. J. T. Mitchell, What Do Pictures Want? The Lives and Loves of Images (University of Chicago Press, 1995), 16, 21, 93.

50. Béla Balázs, Film Theory; in Corrigan and White, The Film Experience, 445, my emphasis.

51. J. T. Page, "Towards a Theory of Visual Narrative Analysis: What We See on HDTV," Paper presented at annual meeting of International Communication Association, Dresden International Congress Centre, 2008-09-13;

http://www.allacademic.com/meta/p91229_index.html

52. Timothy Iles, Abe Kobo: An Exploration of His Prose, Drama, and Theatre (European Press Academic Publishing, 2002); David Mitchell, "No Escape," The Guardian, October 7, 2006;

http://www.guardian.co.uk/books/2006/oct/07/featuresreviews.guardianreview26/print

53. Gregory Stephens, "Feeding Tiger, Finding God: Science, Religion and 'the better story' in Life of Pi," (forthcoming, Intertexts: A Journal of Comparative and Theoretical Reflections); Laura Esquivel, Like Water for Chocolate: A Novel in Monthly Installments, with Recipes, Romances, and Home Remedies. Carol Christensen and Thomas Christensen, trs. (New York. Doubleday, 1992). Film produced and directed by Alfonso Arau, 1991. See Maria Elena de Valdes, "Verbal and Visual Representation of Women: Como agua para chocolate / Like Water for Chocolate," World Literature Today (January 1995).

54. Kevin Thomas, "Woman in the Dunes an Erotic Masterpiece," Los Angeles Times, September 5, 1997.

55. Kelly Oliver, "The Look of Love," Hypatia (June 2001). In her discussion of the loving look as an alternative to the objectifying look, and of a form of recognition beyond domination, Luce Irigaray writes of the need to "gaze together at the invisible." Entre deux. Paris: Grasset, 1997), 78). Translated by Lisa Walsh; quoted in Oliver.

56. Peter Wollen, "Ontology and Materialism in Film" (1976), in Razutis, "Menage a Trois." Jurgen Habermas, Knowledge and Human Interests (London: Heinemann, 1972), p. 314. Thus we can only know "first nature" through language, which for Habermas does not include visuals.

57. Godfrey Reggio in Greg Carson, director, "Essence of Life," included in special features section of the MGM 2002 DVD re-release of Godfrey Reggio, Koyaanisqatsi.

58. better hole, Roger Ebert, "Review of Woman in the Dunes," Chicago Sun Times (2-1-1998);

59. Takuya Ito, "Abe Kobo's Woman in the Dunes as a Metaphor for Human Relations within Japanese Companies," electronic journal of contemporary Japanese studies, Discussion Paper 2 (April 23, 2007); 
http://www.japanesestudies.org.uk/discussionpapers/2007/Ito.html

60. In linking the resolution to a "crisis in masculinity" to a balancing of Eastern and Western philosophy, I am influenced by Charles Johnson's reference to the "crisis in the male spirit" in The Oxherding Tale (Scribner, 2005), 28. This is a reprinting of the Plume 1995 paperback with a new Introduction by the author.

\section{Author Information}

HTML clipboard

GREGORY STEPHENS is teaching film in the English Department at New Mexico State University. From 2004-2008 Stephens was Lecturer in Cultural Studies and Film at the University of West Indies-Mona. While in Jamaica he completed a Masters thesis in Spanish at UWI-Mona, focusing on the poetics of indigenismo in Zapatista discourse. His PhD is in Communication from the University of California-San Diego (1996). Stephens is the author of On Racial Frontiers: The New Culture of Frederick Douglass, Ralph Ellison, and Bob Marley (Cambridge UP, 1999). 